\title{
DIMENSIONS OF HEALTHCARE SERVICES QUALITY BASED ON PERCEPTION OF PRIMARY HEALTHCARE USERS USING FACTOR ANALYSIS
}

\author{
Aldin Brajić 7 , Samira Dedić ${ }^{8}$ \& Saliha Brajić ${ }^{9}$
}

UDC / UDK: 658.89:614

JEL classification / JEL klasifikacija: C14, I11

DOI: https://doi.org/10.22598/pi-be/2021.15.2.41

Preliminary report / Prethodno priopćenje

Received / Primljeno: July 8, 2021 / 8. srpnja 2021.

Accepted for publishing / Prihvaćeno za tisak: October 25, 2021 / 25. listopada 2021.

\section{Summary}

In today's business environment, the demand for better quality health services is becoming imperative. Market openness in the field of primary healthcare has led public health institutions to apply the concept of quality management as a key instrument in the fight against competition. This paper builds on a previously published study on the expectations of primary healthcare users, which now focuses on their perception and recognition of gaps in order to develop a final model of primary healthcare quality management. The research was conducted using a modified SERVQUAL questionnaire on a controlled random sample of 300 primary healthcare users in nine municipalities of Tuzla Canton of Bosnia and Herzegovina. Exploratory factor analysis of the main components based on the orthogonal rotation of VARIMAX was used. The general goal of the research is to use scientific methods to build a final model of quality management of health services in public primary healthcare institutions. Based on the set goal, the central hypothesis is defined, which says that by applying factor analysis it is possible to identify key dimensions and attributes of health service quality from the aspect of perception of primary healthcare users. The research confirms the existence of selected four dimensions of the quality of health services on the scale of perception, so the conclusions and proposals for primary healthcare managers are presented. The limitation of the research process refers to the geographical limitation of the selected

\footnotetext{
${ }^{7}$ Aldin Brajić, PhD candidate, Faculty of Economics of the University of Tuzla, Bosnia and Herzegovina, E-mail address: brajicaldin@gmail.com

${ }^{8}$ Samira Dedić, PhD, Faculty of Economics of the University of Tuzla, Bosnia and Herzegovina, E-mail address: samira.dedic@untz.ba

${ }^{9}$ Saliha Brajić, PhD candidate, Faculty of Economics of the University of Tuzla, Bosnia and Herzegovina, E-mail address: saliha.cabro@yahoo.com
} 
sample, and it is recommended to extend the research to the entire territory of Bosnia and Herzegovina.

Keywords: healthcare; factor analysis; user perception; service quality: model.

\section{INTRODUCTION}

The primary level of healthcare is a pillar of the healthcare systems of each country, covering over $2 / 3$ of all health users' needs. Since the end of the war in Bosnia and Herzegovina there have been noticeable shifts and developments in primary healthcare institutions. Most of the projects were focused on the reconstruction of health facilities and the procurement of basic medical equipment. However the system did not grow out of the public management's awareness of the necessary transparency and the economic necessity of rationalization. In order to improve the primary level of healthcare in Bosnia and Herzegovina, it is necessary to professionalize managerial positions in healthcare institutions, introduce standardized management systems and seek continuous contact with healthcare users. It is also necessary to control the work of the stuff, reward employees based on their results and punish corrupt behavior of healthcare workers.

Given that the highest percentage of first contact with users is achieved at the primary level, the research of perceived and expected quality of health services by users becomes much more important and is a powerful tool for building a quality management model. In doing so, the quality of service is the gap between the perceived level of service that an individual has received in relation to the level of his expectations. By recognizing the points of gaps between what users expect and what they perceive after the service, healthcare management will be able to use the obtained information in order to continuously improve their work and user satisfaction in the future.

The significance of this paper is reflected in the fact that it is also of a pioneering character, and that so far there has been no research on the quality of primary healthcare services in Bosnia and Herzegovina. At the global level, the importance is reflected in the modification of the SERVQUAL model by adapting the questionnaire to the requirements of the primary level of healthcare in order to identify completely new dimensions of the quality of healthcare services.

The central hypothesis of this research proposal is that by applying factor analysis it is possible to identify key dimensions and attributes of healthcare service quality from the aspect of perception of primary healthcare users. Factor analysis will be used to identify key dimensions and attributes of health service quality based on user perception, and the results obtained will be the starting point for building a final model of health service quality management. Concluding remarks will be directed towards applied practical effects of research on whether it is possible to identify key dimensions and attributes of healthcare services quality from the aspect of user perception, with the aim of defining and suggesting ways of directing health institution management towards improving quality of provided healthcare services. In addition to the empirical research, also the theoretical parts that represent the methodological and conceptual framework of the research will be covered in this work. 


\section{PREVIOUS RESEARCH}

Quality management in the healthcare system is becoming the norm, especially when it comes to the availability of healthcare services, safety and reliability of medical practices, quality of service provision, customer satisfaction, and managing the costs of healthcare institutions.

Babakus and Mangold (1992) were pioneers in measuring the quality of healthcare services in case of hospital environment. Their empirical research examined the reliability and value of the instrument. The scale of expectations and perceptions has resulted in one-dimensional constructs, and it has been shown that they can be successfully applied to estimate the size of the gap between expectations and user perceptions. It is for this reason that the authors assessed the model as a concise and practical instrument useful for assessing the quality of healthcare services, and suggested further research and evaluation of the instruments.

By using HEALTHQUAL scale adapted from SERVQUAL scale Miranda et al. (2009) in the context of primary healthcare centers, measured the perceptions service quality, both by the users and the healthcenter managers in Spain. In their research they found out that there was a discrepancy among the users' perceptions and the perceptions of healthcenter managers. Also using factor analysis and multiple regressions, significant associations were found between the service quality dimensions and patient satisfaction.

In their work, Ozretić et al. (2010) presented the results of the conducted research on the quality of healthcare services provided in primary healthcare institutions. The results showed that there is a significant gap between the perceptions and expectations of service users and that the gap is different depending on the dimensions. The largest gap was recorded in the dimensions of "responsibility", "security" and "reliability".

When we talk about the domestic publication in the field of quality management in healthcare, the most famous researcher is Huseinspahić, whose research focus on patients of clinical centers (tertiary level of healthcare). Starting from the basic characteristics of the model of measuring quality Huseinspahic (2012) presented the results of research conducted among healthcare users and measuring the impact of their previous expectations on the perception of service quality using a weighted SERVQUAL model based on the difference between perceived and expected quality. The results of the research showed that the level of previous expectations is extremely high for the perception of the level of functional quality for certain types of services at the Clinical Center Tuzla.

Papanikolaou and Zygiaris (2014) tested the internal consistency and applicability of SERVQUAL in primary healthcare centres in Greece. Their research showed that there were gaps in all dimensions, while the largest gap was detected in "empathy". They also showed that there were also differences depending on gender, age and education levels. A separate analysis of expectations and perceptions revealed that this gap was because of differences in patients' perceptions rather than expectations.

Aghamolaei et al. (2014) have conducted cross sectional study in 2013 in Bandar Abbas Shahid Mohammadi Hospital in the south of Iran. All 96 participants of this study were provided by SERVQUAL questionnaire. Data was analyzed by Wilcoxon and 
Kruskal-Wallis tests. According to the results, this hospital was not able to meet patients' expectations completely. The lowest perception was in responsiveness dimension and the lowest expectation was about empathy.

Mečev and Goleš (2015) examined in their research quality perceptions of primary healthcare users. They sought to determine whether there was a difference between user expectations and levels of satisfaction with the medical service received. They found a gap in all dimensions, and that there is no difference in the perception of service quality with respect to age and gender of users, but that there is a significant difference in satisfaction with employment status and frequency of service use.

Amaravathi and Anand Shankar Raja (2016) published one close research to this paper on the expectations of primary healthcare users in case of the City of Coimbatore (India). Their aim was to present a framework that can be used to identify the expectations of the general public with regard to primary healthcare services, taking into consideration the SERVQUAL dimensions. By applying factor analysis to a sample of 80 respondents, they were able to identify as many as 8 factors of satisfaction of healthcare users.

According to Kljaic (2017) the assessment and measurement of user safety is a significant indicator of the quality of work of a healthcare institution and at the same time serves as a starting point for planning and taking improvement measures. Monitoring and analysis of adverse events and organizational practices of user safety contributes to the knowledge of causes, prevention and safe practice and helps prevent future adverse effects of hospital care, to reduce their long-term adverse effects and shorten treatment duration and reduce treatment costs. The most important dimension of healthcare and the priority of any healthcare system is safety and the user at the center of care and we must strive to make the system as safe as possible, both for the user and for all those who provide healthcare. Risk assessment is a process that helps to understand the range of risks we face, the level of ability to control these risks, their likelihood of occurrence and their potential consequences. It is not enough just to detect existing risks, but it is necessary to take preventive measures, analyze possible causes, and take measures to improve.

The aim of Stojčić's research (2017) was to determine the quality of laboratory services of the medical-biochemical laboratory of the Osijek Healthcare Center from the point of view of its users. The survey was conducted on 400 respondents. In addition to the socio-demographic data of the respondents, the research determined the assessment of functional quality, technical quality, and the overall quality assessment of the medicalbiochemical laboratory. The quality of laboratory services of the users of the city of Osijek was rated with a high score of 6.1 on the Likert scale from 1 to 7 . Furthermore, the technical quality of the laboratory was rated at 6.8 while the functional quality was rated slightly lower, at 5.9. This research indicated a high assessment of the quality of laboratory services in the medical-biochemical laboratory at the primary level of healthcare in the city of Osijek by the users of the mentioned services.

Čakalić (2018) measured user satisfaction with the quality of healthcare with regard to age, gender, level of education, employment status and reason for hospitalization. The standardized Laschinger HCAHPS (Hospital Consumer Assessment of Healthcare Providers and Systems) questionnaire was used, as well as the NPSCC 
(Patient Satisfaction with Nursing Care Quality Questionnaire) questionnaire, with three thematic dimensions in relation to the Risser scale: interpersonal relationship and trust, education and information and technical-professional competencies in nursing. Respondents rated the quality of healthcare as excellent. They were extremely satisfied with the quality of healthcare provided at the Clinical Institute for Nuclear Medicine and Radiation Protection in Osijek. They were also pleased with the relationship with the nurses and technicians. There were statistically significant differences with respect to age, employment status, vocational education, and reason for hospitalization. There was no significant statistical difference by gender.

Teshinzi et al. (2018) through a meta-analysis of all Iranian studies of primary and other healthcare centers found that gaps between mean scores for expectations and perceptions were negative for all five dimensions of the SERVQUAL tool. This research implies that patients in Iran are not fully satisfied with the quality of healthcare services. Improvements are needed, and so this study presents an opportunity to identify areas of strengths and weakness in the quality of healthcare provided by health organizations in Iran.

By using factor analysis Brajić et al. (2021) confirmed the existence of five dimensions of the quality of health services in the expectation scale. The five-dimensional solution to the expectation scale resulted in the following factors: (1) Reliability of health personnel and transparency of health information, (2) Competence and assurance of health professionals, (3) Infrastructure and technical equipment of the health institution, (4) Resolving user requests, problems and remarks by health and administrative staff, and (5) Consistency and information in the provision of health services. The survey has been conducted based on controlled sampling of primary healthcare users in the area of nine municipalities in the Tuzla Canton. The presented research is the predecessor and basis for the development of this paper, which now focuses on the scale of perception and completes the overall picture with the development of the final model of primary healthcare quality management.

\section{RESEARCH METHODOLOGY}

Within the elaboration of certain theoretical and methodological starting points of the observed problem, and certain applied considerations, the following methods were used: induction and deduction method, analysis and synthesis method, hypotheticaldeductive method, analytical-deductive method, comparative method, method of logical reasoning, understanding and interpretations and methods based on statistical analysis (exploratory factor analysis in which the principal components method was based on orthogonal rotation VARIMAX), and to confirm or reject the central hypothesis: $B y$ applying factor analysis it is possible to identify key dimensions and attributes of healthcare service quality from the aspect of perception of primary healthcare users. Empirical research was conducted based on the application of professional and scientific methods of secondary and primary research. As part of the secondary research, the paper used published scientific and professional papers that treat this issue. A reconnaissance 
or exploratory research was conducted, within which secondary data were collected and previous experiences were researched. Secondary sources referred to the available relevant literature in the field of service quality management, healthcare and customer satisfaction. Primary research collected data using a survey method, using a survey questionnaire as a means of data collection. For the purpose of conducting the primary research, as mentioned, the examination method (written examination technique) was used.

Dimensions of the healthcare services quality of that can be identified within the primary activities of the process of providing healthcare services are observed through: tangibles, reliability, responsiveness, competence and assurance and empathy. The "tangibles" dimension includes questions A1 to A4 and includes the physical appearance and the entire property of the health institution, such as: equipment, arrangement of health institutions, uniformity of staff, promotional materials, etc. The "reliability" dimension includes questions A5 to A9 and includes the provision of health services without error, the provision of health services at the agreed time, interest in solving problems, etc. The "responsiveness" dimension includes questions A10 to A13 and involves providing sufficient time and attention to each individual healthcare user. The "competence and assurance" dimension includes questions A14 to A19 and includes the knowledge, abilities and skills of medical staff, which instill confidence in healthcare users. The "empathy" dimension includes questions A20 to A24 and involves individual attention, care and understanding of the specific needs of healthcare users. Dimensional scale was taken from the reduced SERVQUAL created in 1988 by the authors Parasuraman, Zeithmal and Berry (Šiško-Kuliš and Grubšić, 2010) while the claims (indicators) within the dimensions were modified according to the nature of primary healthcare services in Bosnia and Herzegovina. A five-level Likert scale was used (from 1 - I completely disagree, to 5- I completely agree).

Data collection was performed on the basis of a proportional stratified sample, since it belongs to the category of random samples which allows to assess degree of reliability of conclusions about the investigated parameters. The total number of distributed survey questionnaires was 500, with 300 questionnaires adequately completed. Thus, the rate of return of the survey questionnaires was relatively high and amounted to $60 \%$. The survey was conducted in healthcare centers in nine municipalities of Tuzla Canton, which we randomly selected from a total of thirteen municipalities, and users of healthcare services were surveyed based on their availability in healthcare centers of these municipalities.

\section{EMPIRICAL RESEARCH}

The dimensions of healthcare services, measured using the perception scale, were subjected to factor analysis to test the central hypothesis: By applying factor analysis it is possible to identify key dimensions and attributes of healthcare service quality from the aspect of perception of primary healthcare users. Thus, we will try to find out whether there are basic dimensions or factors, or whether they coincide with the five dimensions 
of the process of providing healthcare services. (tangibles, reliability, responsiveness, competence and assurance and empathy). It should be noted that only those factors that meet the following conditions are significant (Hair et al., 1998):

- their eigenvalues must be greater than one,

- percentage of total variance greater than or equal to 0.60 (in social research),

- the significance of the factor coefficient is greater than or equal to 0.50 .

Necessary conditions were examined in order to determine the suitability of the data for the application of factor analysis. The variables that are analyzed by factor analysis must be quantitative, which is met in our research, bearing in mind the fact that these are numerical variables. One of the conditions is certainly the correlation between the original variables, which was established on the basis of the correlation matrix. To examine the adequacy of the data, the Kaiser-Meyer-Olkin measure was applied to all variables together. The Kaiser-Meyer-Olkin Measure of Sampling Adequacy ranges from 0 to 1 . Values less than 0.5 are indicating that the correlation matrix is unsuitable for factor analysis while value of 0.6 is recommended as acceptable for good factor analysis (Tabachnick and Fidell, 2007).

The following table shows the values of the Bartlett's test of sphericity and the KMO coefficient for the whole sample. Both tests are essential to assess the feasibility of factor analysis.

Table 1. KMO coefficient and Bartlett's test scale of perceptions

\begin{tabular}{|l|r|r|}
\hline \multicolumn{2}{|c|}{ Description } & \multicolumn{1}{c|}{ Values } \\
\hline Kaiser-Meyer-Olkin Measure of Sampling Adequacy & .933 \\
\hline Bartlett's Test of Sphericity & Approx. Chi-Square & 4466.985 \\
\cline { 2 - 3 } & df & 276 \\
\cline { 2 - 3 } & Sig. & .000 \\
\hline
\end{tabular}

Source: authors

Bartlett's test is used to test the null hypothesis that there is no significant correlation between the original variables. In other words, the correlation matrix of the respondents is a unit matrix, meaning each variable is correlated with itself and there is no correlation with the other variable. The basis for applying Bartlett's test is the ChiSquare test. Based on the value of significant parameters from the previous table we can reject the null hypothesis, which means that there is a significant correlation between the original variables. Since the Kaiser-Meyer-Olkin measure in our case is 0.933 , we can conclude that the data of the variables used are suitable for conducting factor analysis.

In the following, we will describe the results of the factor analysis based on the scale of perceptions of healthcare users. Factor analysis of the main components was applied in the research. The basis for its implementation was an unreduced correlation matrix, where units are used for the initial utilities, that is, units are located on the main diagonal of the correlation matrix. By applying the factor analysis of the principal components after the transformation of the variables on the orthogonal axis has been carried out, the factors are extracted on the basis of their eigenvalues. Table 2 shows the 
factor structure of the scale of perceptions of healthcare users after the analysis of the main components.

Table 2. Unrotated component analysis factor matrix

\begin{tabular}{|c|c|c|c|c|c|c|}
\hline & \multirow{2}{*}{ Question (Variable) } & \multicolumn{4}{|c|}{ Component matrix } & \multirow{2}{*}{ Communalities } \\
\hline & & 1 & 2 & 3 & 4 & \\
\hline A17 & $\begin{array}{l}\text { Behaviour of healthcare } \\
\text { staff gives confidence to } \\
\text { the users. }\end{array}$ & .808 & $\begin{array}{c}- \\
.178\end{array}$ &.- & 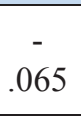 & .747 \\
\hline $\mathrm{A} 12$ & $\begin{array}{l}\text { Medical staff is always } \\
\text { ready to respond to the } \\
\text { demands of healthcare } \\
\text { users. }\end{array}$ & .798 & .018 & .229 & $\begin{array}{c}- \\
.070\end{array}$ & .695 \\
\hline A11 & $\begin{array}{l}\text { The medical staff has, } \\
\text { during the examination, } \\
\text { dedicated enough time and } \\
\text { attention to each patient. }\end{array}$ & .776 & .030 &. & .037 & .743 \\
\hline A10 & $\begin{array}{l}\text { Medical staff treats } \\
\text { patients with respect. }\end{array}$ & .773 & .139 & $\begin{array}{c}- \\
.313\end{array}$ & .100 & .725 \\
\hline A21 & $\begin{array}{l}\text { All healthcare staff is kind } \\
\text { to healthcare users. }\end{array}$ & .772 & .015 &.- & 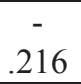 & .708 \\
\hline A14 & $\begin{array}{l}\text { Medical staff provides the } \\
\text { patient with the necessary } \\
\text { advice, information on } \\
\text { testing, treatments, } \\
\text { therapies and treatment } \\
\text { costs. }\end{array}$ & .769 & $\begin{array}{c}- \\
.190\end{array}$ & .247 & .024 & .689 \\
\hline A7 & $\begin{array}{l}\text { The healthcare staff helps } \\
\text { patients in solving their } \\
\text { problems. }\end{array}$ & .756 & $\begin{array}{c}- \\
.166\end{array}$ & .159 & $\begin{array}{c}- \\
.100\end{array}$ & .634 \\
\hline A5 & $\begin{array}{l}\text { The healthcare institution } \\
\text { insists on providing health } \\
\text { services without mistakes. }\end{array}$ & .749 & .030 & .083 & $\begin{array}{c}- \\
.300\end{array}$ & .659 \\
\hline A23 & $\begin{array}{l}\text { When staying in a } \\
\text { healthcare facility, service } \\
\text { users feel safe (using lifts, } \\
\text { medical equipment, } \\
\text { violent behaviour and } \\
\text { personal safety). }\end{array}$ & .745 & $\begin{array}{c}- \\
.015\end{array}$ & .045 & $\begin{array}{c}- \\
.126\end{array}$ & .574 \\
\hline A18 & $\begin{array}{l}\text { The healthcare staff has } \\
\text { the appropriate knowledge } \\
\text { and skills to be able to } \\
\text { meet the needs of the } \\
\text { users. }\end{array}$ & .726 & $\begin{array}{c}- \\
.202\end{array}$ & .085 & .142 & .595 \\
\hline
\end{tabular}




\begin{tabular}{|c|c|c|c|c|c|c|}
\hline A22 & $\begin{array}{l}\text { Healthcare users are } \\
\text { satisfied with waiting } \\
\text { room conditions (e.g. } \\
\text { hygiene, room warming, } \\
\text { etc.). }\end{array}$ & .718 & .049 & $\begin{array}{c}- \\
.142\end{array}$ & 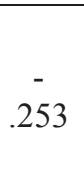 & .602 \\
\hline A9 & $\begin{array}{l}\text { The health service is } \\
\text { flawlessly provided during } \\
\text { first visit. }\end{array}$ & .710 & .217 &.- & .035 & .612 \\
\hline A20 & $\begin{array}{l}\text { Medical staff provides } \\
\text { information or advice } \\
\text { regarding the user's } \\
\text { (patient) or state of user. }\end{array}$ & .692 & .298 & .114 & .073 & .586 \\
\hline A 15 & $\begin{array}{l}\text { Medical staff talks to the } \\
\text { patient about health } \\
\text { protection and disease } \\
\text { prevention (e.g. quit } \\
\text { smoking, weight loss, diet, } \\
\text { exercise, etc.). }\end{array}$ & .680 &.- & .367 & .118 & .731 \\
\hline A19 & $\begin{array}{l}\text { Information that } \\
\text { healthcare users own } \\
\text { which is related to the } \\
\text { health condition of the } \\
\text { service user is protected } \\
\text { and not publicly disclosed. }\end{array}$ & .653 & .269 & $\begin{array}{c}- \\
.062\end{array}$ & .266 & .573 \\
\hline A16 & $\begin{array}{l}\text { The healthcare staff } \\
\text { explains to the patient } \\
\text { when they need to come to } \\
\text { a check, therapy or other } \\
\text { treatment. }\end{array}$ & .610 &.- & .298 & .436 & .757 \\
\hline A8 & $\begin{array}{l}\text { Health service is provided } \\
\text { in a pre-agreed term. }\end{array}$ & .602 & .223 & .058 & .343 & .533 \\
\hline A6 & $\begin{array}{l}\text { Health service users are } \\
\text { familiar with the ability } \\
\text { and conditions under } \\
\text { which team members } \\
\text { make a home visit. }\end{array}$ & .580 & .227 & .340 & $\overline{-} \cdot-$ & .715 \\
\hline A3 & $\begin{array}{l}\text { Staff of the healthcare } \\
\text { institution are adequately } \\
\text { trained (uniform, neat } \\
\text { appearance, accreditation, } \\
\text { etc.). }\end{array}$ & .536 & .392 & .113 & .383 & .601 \\
\hline A24 & $\begin{array}{l}\text { The prices of healthcare } \\
\text { services are reasonable. }\end{array}$ & .524 & .027 & .347 & $\begin{array}{c}- \\
.164\end{array}$ & .423 \\
\hline A 13 & $\begin{array}{l}\text { Patient is asked for consent } \\
\text { for a third person when a } \\
\text { diagnostic or therapeutic } \\
\text { procedure is performed. }\end{array}$ & .503 & .081 & $\begin{array}{c}- \\
.198\end{array}$ & .061 & .302 \\
\hline
\end{tabular}




\begin{tabular}{|c|l|l|l|l|l|l|}
\hline A4 & $\begin{array}{l}\text { Materials related to health } \\
\text { services such as prospects, } \\
\text { catalogues, brochures are } \\
\text { visually attractive. }\end{array}$ & .479 & .523 & .242 & $\begin{array}{c}- \\
.129\end{array}$ & .578 \\
\hline A1 & $\begin{array}{l}\text { Healthcare institution has } \\
\text { modern equipment } \\
\text { (equipment, instruments). }\end{array}$ & .409 & .682 & .190 & - & .075 \\
\hline A2 & $\begin{array}{l}\text { Facilities of healthcare } \\
\text { institution have attractive } \\
\text { appearance (facility, } \\
\text { lightning, signs, etc.) }\end{array}$ & .377 & .731 & .176 & .084 & .715 \\
\hline
\end{tabular}

\section{Source: authors}

From the previous table we can see that the structure consists of four extracted factors. The communality of a variable shows how much that variable is already known or explained, meaning, it shows how much the variance of that variable is explained by common factors. Low utility values indicate variables that could be omitted from the analysis. In fact, the higher the utility, the more familiar is the variable. The communality of all factors in this study ranges from 0.302 to 0.757 . The following table shows the eigenvalues for the extracted factors as well as the values for the total variance. The following table shows the results of factor extraction.

Table 3. Matrix of factor structure, eigenvalues and explained variance - results of extracted factors of the scale of perceptions of healthcare users

\begin{tabular}{|c|c|c|c|c|c|c|c|c|c|}
\hline \multirow{2}{*}{ 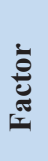 } & \multicolumn{3}{|c|}{ Initial Eigenvalues } & \multicolumn{3}{|c|}{$\begin{array}{l}\text { Extraction Sums of } \\
\text { Squared Loadings }\end{array}$} & \multicolumn{3}{|c|}{$\begin{array}{c}\text { Rotation Sums of Squared } \\
\text { Loadings }\end{array}$} \\
\hline & Eigenv. & $\begin{array}{l}\% \text { of } \\
\text { Var. }\end{array}$ & Ситиц.\% & Eigenv. & $\begin{array}{l}\% \text { of } \\
\text { Var. }\end{array}$ & Cumul.\% & Eigenv. & $\begin{array}{l}\% \text { of } \\
\text { Var. }\end{array}$ & Ситul..\% \\
\hline 1 & 10.704 & 44.599 & 44.599 & 10.704 & 44.599 & 44.599 & 5.843 & 24.347 & 24.347 \\
\hline 2 & 2.132 & 8.882 & 53.481 & 2.132 & 8.882 & 53.481 & 3.383 & 14.096 & 38.444 \\
\hline 3 & 1.252 & 5.216 & 58.697 & 1.252 & 5.216 & 58.697 & 3.018 & 12.577 & 51.020 \\
\hline 4 & 1.084 & 4.518 & 63.215 & 1.084 & 4.518 & 63.215 & 2.927 & 12.195 & 63.215 \\
\hline 5 & .919 & 3.827 & 67.042 & & & & & & \\
\hline 6 & .827 & 3.444 & 70.486 & & & & & & \\
\hline 7 & .790 & 3.293 & 73.780 & & & & & & \\
\hline 8 & .705 & 2.937 & 76.716 & & & & & & \\
\hline 9 & .629 & 2.622 & 79.338 & & & & & & \\
\hline 10 & .542 & 2.259 & 81.597 & & & & & & \\
\hline 11 & .524 & 2.184 & 83.781 & & & & & & \\
\hline 12 & .462 & 1.926 & 85.706 & & & & & & \\
\hline 13 & .417 & 1.737 & 87.443 & & & & & & \\
\hline
\end{tabular}




\begin{tabular}{|l|c|c|c|l|l|l|l|l|l|}
\hline 14 & .386 & 1.607 & 89.050 & & & & & & \\
\hline 15 & .384 & 1.598 & 90.648 & & & & & & \\
\hline 16 & .327 & 1.364 & 92.012 & & & & & & \\
\hline 17 & .298 & 1.242 & 93.254 & & & & & & \\
\hline 18 & .289 & 1.202 & 94.457 & & & & & & \\
\hline 19 & .263 & 1.095 & 95.552 & & & & & & \\
\hline 20 & .255 & 1.062 & 96.614 & & & & & & \\
\hline 21 & .234 & .974 & 97.588 & & & & & & \\
\hline 22 & .220 & .918 & 98.505 & & & & & & \\
\hline 23 & .198 & .826 & 99.331 & & & & & & \\
\hline 24 & .161 & .669 & 100.000 & & & & & & \\
\hline
\end{tabular}

Source: authors

Table 3 shows the eigenvalues for the extracted factors as well as the values for the total variance. The eigenvalues (total) for the four extracted factors are 10.704 (first factor), 2.132 (second factor), 1.252 (third factor), and 1.084 (fourth factor), which means that the first four factors have critical values greater than 1 , and these factors explain $63.215 \%$ of the variance. It is noticeable that the percentage of total variance for the relevant factors is higher than $0.60(60 \%)$, which is the lower permissible limit in social research.

Table 4 shows the factor structure matrix for 24 variables after the VARIMAX factor rotation was performed. The results show that the structure of factor loads was changed, meaning that factor loads were distributed on all four factors, which was not the case with the non-rotating matrix. The structure of factor loads after the rotation enables better interpretation of factors in relation to the initial factor matrix. The table also lists the utilities for each individual variable and the eigenvalues of the selected factors after the rotation of the factors.

Table 4. Matrix of the factor structure of the perception scale after orthogonal VARIMAX factor rotation

\begin{tabular}{|c|c|c|c|c|c|}
\hline \multirow{2}{*}{\multicolumn{2}{|c|}{ Question (Variable) }} & \multicolumn{4}{|c|}{ Component matrix } \\
\hline & & 1 & 2 & 3 & 4 \\
\hline A11 & $\begin{array}{l}\text { The medical staff has, during the examination, } \\
\text { dedicated enough time and attention to each } \\
\text { patient. }\end{array}$ & .803 & .236 & .116 & .171 \\
\hline A10 & Medical staff treats patients with respect. & .753 & .257 & .077 & .293 \\
\hline A17 & $\begin{array}{l}\text { Behaviour of healthcare staff gives confidence to } \\
\text { the users. }\end{array}$ & .741 & .314 & .315 & .022 \\
\hline $\mathrm{A} 21$ & All healthcare staff is kind to healthcare users. & .738 & .122 & .363 & .129 \\
\hline
\end{tabular}




\begin{tabular}{|c|c|c|c|c|c|}
\hline A12 & $\begin{array}{l}\text { Medical staff is always ready to respond to the } \\
\text { demands of healthcare users. }\end{array}$ & .726 & .246 & .285 & .164 \\
\hline A9 & $\begin{array}{l}\text { The health service is flawlessly provided during } \\
\text { first visit. }\end{array}$ & .666 & .176 & .112 & .354 \\
\hline A 22 & $\begin{array}{l}\text { Healthcare users are satisfied with waiting room } \\
\text { conditions (e.g. hygiene, room warming, etc.). }\end{array}$ & .623 & .088 & .409 & .198 \\
\hline A23 & $\begin{array}{l}\text { When staying in a healthcare facility, service users } \\
\text { feel safe (using lifts, medical equipment, violent } \\
\text { behaviour and personal safety). }\end{array}$ & .562 & .251 & .395 & .197 \\
\hline A18 & $\begin{array}{l}\text { The healthcare staff has the appropriate knowledge } \\
\text { and skills to be able to meet the needs of the users. }\end{array}$ & .554 & .487 & .218 & .049 \\
\hline A13 & $\begin{array}{l}\text { Patient is asked for consent for a third person when } \\
\text { a diagnostic or therapeutic procedure is performed. }\end{array}$ & .486 & .170 & .058 & .183 \\
\hline A16 & $\begin{array}{l}\text { The healthcare staff explains to the patient when } \\
\text { they need to come to a check, therapy or other } \\
\text { treatment. }\end{array}$ & .177 & .830 & .184 & .056 \\
\hline A15 & $\begin{array}{l}\text { Medical staff talks to the patient about health } \\
\text { protection and disease prevention (e.g. quit } \\
\text { smoking, weight loss, diet, exercise, etc.). }\end{array}$ & .203 & .678 & .478 & .038 \\
\hline A19 & $\begin{array}{l}\text { Information that healthcare users own which is } \\
\text { related to the health condition of the service user is } \\
\text { protected and not publicly disclosed. }\end{array}$ & .477 & .574 & .126 & $\begin{array}{c}- \\
.009\end{array}$ \\
\hline A14 & $\begin{array}{l}\text { Medical staff provides the patient with the } \\
\text { necessary advice, information on testing, } \\
\text { treatments, therapies and treatment costs. }\end{array}$ & .358 & .546 & .488 & .157 \\
\hline A 20 & $\begin{array}{l}\text { Medical staff provides information or advice } \\
\text { regarding the user's (patient) or state of user. }\end{array}$ & .395 & .537 & .376 & .003 \\
\hline A6 & $\begin{array}{l}\text { Health service users are familiar with the ability } \\
\text { and conditions under which team members make a } \\
\text { home visit. }\end{array}$ & .201 & .174 & .803 & .024 \\
\hline A5 & $\begin{array}{l}\text { The healthcare institution insists on providing } \\
\text { health services without mistakes. }\end{array}$ & .489 & .162 & .575 & .252 \\
\hline A7 & $\begin{array}{l}\text { The healthcare staff helps patients in solving their } \\
\text { problems. }\end{array}$ & .422 & .411 & .519 & .130 \\
\hline A24 & The prices of healthcare services are reasonable. & .132 & .252 & .516 & .275 \\
\hline A2 & $\begin{array}{l}\text { Facilities of healthcare institution have attractive } \\
\text { appearance (facility, lightning, signs, etc.) }\end{array}$ & .130 & .004 & .034 & .835 \\
\hline A1 & $\begin{array}{l}\text { Healthcare institution has modern equipment } \\
\text { (equipment, instruments). }\end{array}$ & .156 & $\begin{array}{c}- \\
.065 \\
\end{array}$ & .178 & .784 \\
\hline A4 & $\begin{array}{l}\text { Materials related to health services such as } \\
\text { prospects, catalogues, brochures are visually } \\
\text { attractive. }\end{array}$ & .173 & .015 & .308 & 673 \\
\hline A3 & $\begin{array}{l}\text { Staff of the healthcare institution are adequately } \\
\text { trained (uniform, neat appearance, accreditation, } \\
\text { etc.). }\end{array}$ & .261 & .399 & .065 & .607 \\
\hline A8 & Health service is provided in a pre-agreed term. & .350 & .450 & .002 & .457 \\
\hline
\end{tabular}

\section{Source: authors}


Based on the results shown in Table 4, we can identify the first factor which we called "Resolving user requests, problems and remarks by health and administrative staff'. It includes first 10 variables (from A11 to A13) and explains $44.599 \%$ of the total variance in the data.

The second indentified factor is called "Competence and assurance of health professionals". Includes the following 5 variables shown in Table 4 (from A16 to A20) and explains $8.882 \%$ of the total variance in the data.

"Consistency and information in the provision of health services", interprets the third factor. This factor includes next 4 variables (from A6 to A24) and explains 5.216\% of the total variance in the data.

The last indentified factor is called "Infrastructure and technical equipment of the health institution", where the mentioned factor includes 5 variables (from A2 to A8) and explains $4.518 \%$ of the total variance in the data.

Based on previous detailed analyses of the conducted empirical research, we can conclude that the central research hypothesis is confirmed, that by applying factor analysis it is possible to identify key dimensions and attributes of healthcare service quality from the aspect of perception of users of primary healthcare services.

\section{PROPOSAL OF A MODEL FOR QUALITY MANAGEMENT OF HEALTH SERVICES IN PUBLIC INSTITUTIONS PRIMARY HEALTHCARE}

In order to build the final model of quality management of health services in public primary healthcare institutions, we begin from the starting model. Construction the final model starts from dimensions of quality of health services, to see if, and to what extent, they provide the necessary information managers in order to minimize gaps in the quality of health services. Quality model for health services would also empower a continuous improvement of business process in primary healthcare institutions. To identify the most important dimension of the quality of health services, for the purpose of construction of final model we used factor analysis of major components based on expectation and perception scale. The expectation scale was used from the work of Brajic et al. (2021) relating to quality of health services from the aspect of user expectations. Adding the results of this research on the perception of healthcare users, presented in this paper, we create the final model of measuring the quality of the health services shown in Figure 1. 
Figure 1. The final model for measuring the quality of healthcare services

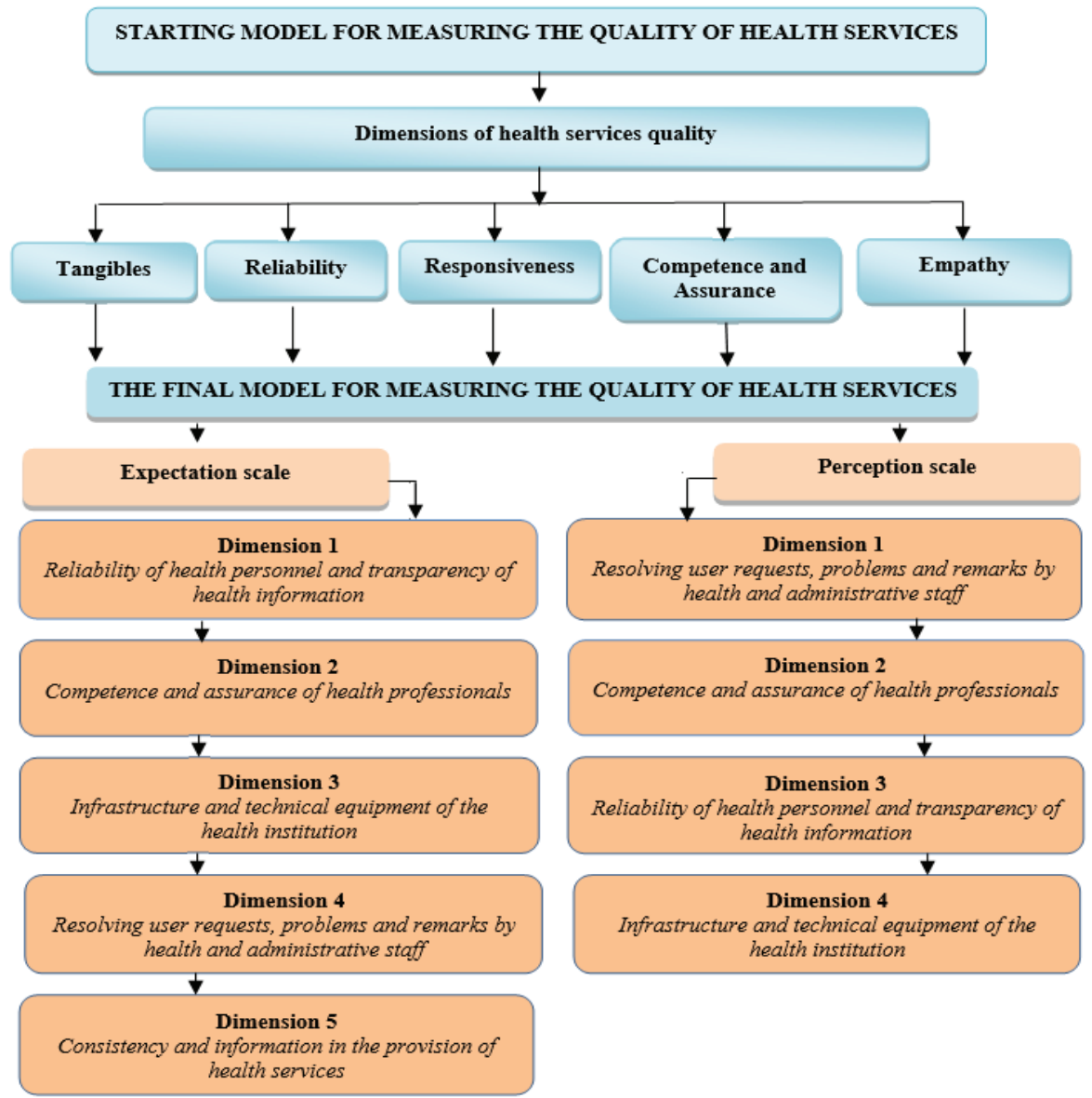

Source: authors 
Figure 2. The final model of primary healthcare quality management

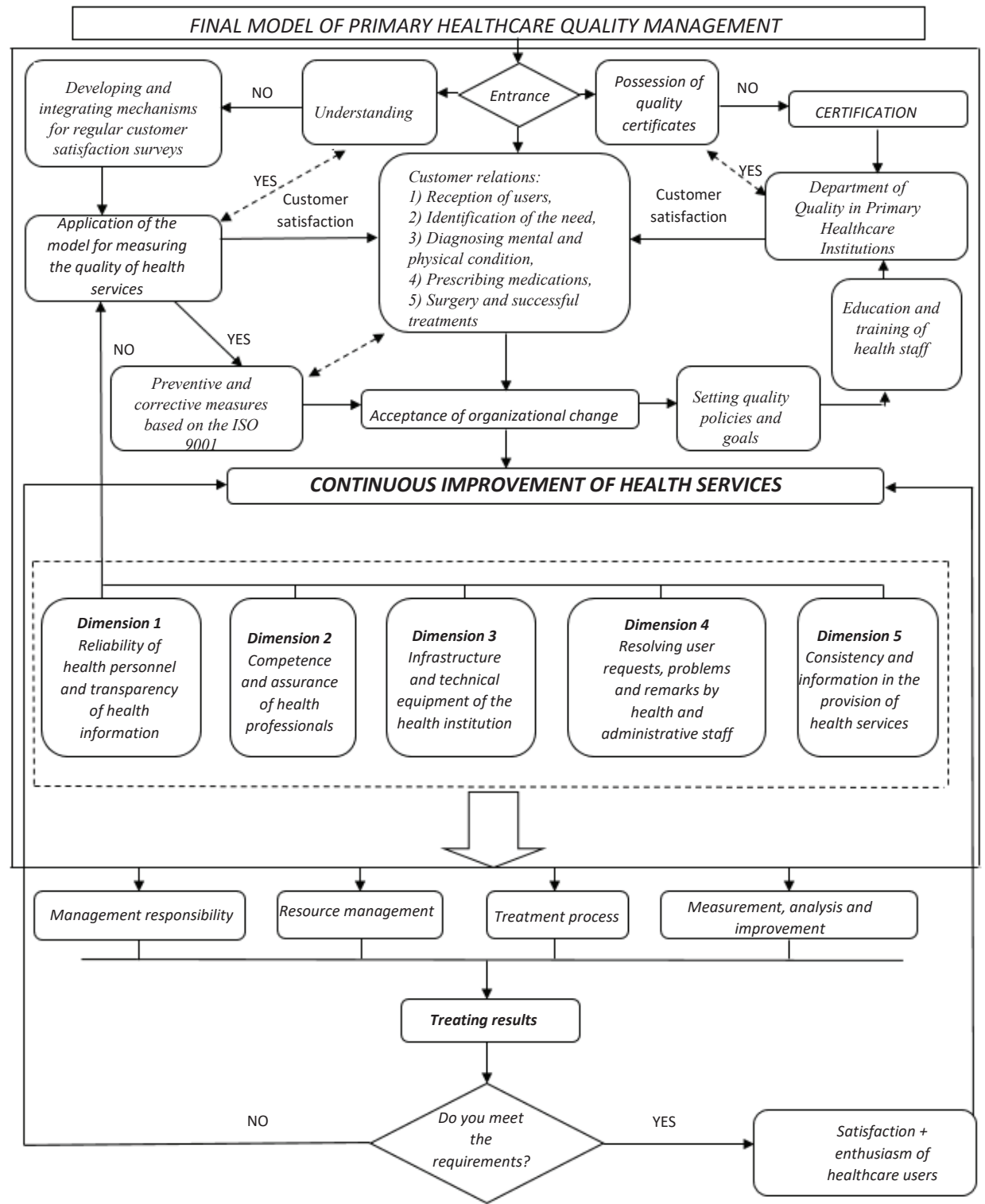

Source: authors

We integrated the model for measuring the quality of health services into the final quality management model of primary healthcare. We also showed the importance of applying the chosen methodology to help managers minimize gaps (differences) 
between dimensions of quality of health services, which would ultimately result in continuous business process improvement in the health sector. The final model of primary healthcare quality management is presented in Figuure 2.

The final model of primary healthcare quality management indicates the complexity of the process of providing health services. Factors that affect the satisfaction of healthcare users are numerous. Starting from the process of providing health services, it is necessary to understand and also to meet the requirements of users. In case of misunderstanding of the requirements that users have, it is important to design and integrate mechanisms for regular examination of the degree of satisfaction of the same. The level of satisfaction of healthcare users will depend on the application of the identified dimensions of healthcare quality using factor analysis.

Continuing the above, a better relationship will be established with the healthcare users when their needs are identified, their admission is made, diagnoses established, medications prescribed, and surgical procedures and successful treatments are performed. On the other hand, primary healthcare centers should have quality certificates. This primarily refers to the ISO 9001 (Quality Management System) in order to meet the requirements and needs of healthcare users. The quality policy clearly indicates the intention and goals of the organization from the aspect of quality, which was defined by the management of primary healthcare. Quality goals should be clear, measurable, achievable, sustainable, and timed so that management can determine the level of its achievement. The quality policy indicates the importance of continuous education and training of medical staff, in order to meet or even exceed the expectations of healthcare users.

The introduction of a quality management system requires medical staff to adapt to organizational change, which would imply continuous improvement of health services. Of course, resistance to change is a normal human reaction. The reasons are numerous: lack of knowledge, skills and abilities, fear of losing the existing organizational position, fear of dismissal, etc. However, in order to eliminate the aversion to the introduction of a quality management system, we recommend that primary healthcare institutions continuously organize seminars on the quality management system.

Continuous improvement of primary healthcare will depend on four group processes:

1) Management responsibility - contains quality policies and goals, internal communications and review of QMS primary healthcare,

2) Resource management - contains processes necessary to achieve quality goals of primary healthcare,

3) Treatment process - contains processes for the implementation of health services according to the requirements of users/patients,

4) Measurement, analysis and improvement - contains processes for measurement, analysis and improvement of health services, processes and QMS of the primary healthcare institution.

The results of treatment will depend on the previous four group processes, which should be continuously improved in order to overcome dissatisfaction and achieve satisfaction and enthusiasm of healthcare users. 


\section{CONCLUSION AND DISCUSSION}

For each primary healthcare institution, it is extremely important to define quality policies and goals in order to achieve total quality management. This means designing such performance standards and strategic goals of health facilities, which will direct them towards growth and development. In this regard, it is crucial to establish a system and processes that will improve the efficiency and effectiveness of the health sector, increase the responsibility of the management of healthcare institutions, reduce expenditures and better meet the requirements and needs of healthcare users.

To identify the most important dimensions of healthcare service quality, we used factor analysis of the main components. The results of the conducted factor analysis confirm the existence of four dimensions of the quality of health services in the perception scale, which are highlighted in the baseline model. The four-dimensional solution to the perception scale resulted in the following factors: (1) Resolving user requests, problems and remarks by health and administrative staff, (2) Competence and assurance of health professionals, (3) Reliability of health personnel and transparency of health information, and (4) Infrastructure and technical equipment of the health institution. Based on previous detailed analyses and discussions of the results of the conducted empirical research, we confirmed the central research hypothesis that by applying factor analysis it is possible to identify key dimensions and attributes of healthcare service quality from the aspect of perception of users of primary healthcare services.

This paper is unique considering that on the territory of Bosnia and Herzegovina, according to the available literature, no research has ever been conducted on the perception of quality provided at the primary level of healthcare, nor has a quality management model been built at the primary level of healthcare. The only previous research on the topic of quality management in healthcare in Bosnia and Herzegovina was done by Huseinspahić, but at the tertiary level of healthcare. His work was actually a case study on the example of University clinic centre Tuzla, so it is not possible to directly compare the obtained results.

Globally, the application of factor analysis in measuring the quality of health services in India by Amaravathi and Anand Shankar Raja has resulted in 8 factors, but it should be emphasized that these are the expectations of primary healthcare users on a smaller sample. On the other hand, our work focuses on the perception of users and a much larger number of respondents, which may be the cause of differences in the results obtained.

We conclude that based on the results of empirical research, it is possible to propose a model for measuring the quality of health services in public primary healthcare institutions, in order to minimize quality gaps, and thus improve customer satisfaction. Ultimately, it is important to identify and recognize the importance of different dimensions of the quality of health services and set realistic expectations, and accordingly create a balanced health system.

As more healthcare institutions are accepting quality, as a valuable tool in the fight against competition, so can this results help to allocate limited resources to the dimensions that are most important to healthcare users. An additional benefit of 
implementation of presented model is reflected in the possibility of feedback from service users themselves, who by meeting their expectations in terms of quality, are more motivated to improve their own health, following more instructions from medical staff.

In order to be able to use the conclusions of this research effectively, it is necessary to take into account certain limitations of the research. We emphasize that this work is limited to the area of Tuzla Canton and in order to reach an overall conclusion or comparative analysis it is recommended to perform the same as testing and research at the level of the entire Bosnia and Herzegovina. Secondary and tertiary levels of healthcare should also be included in the sample. In addition, further research is needed to examine managers, in order to gain a detailed insight into the expectations and perceptions of internal and external healthcare users. It is also important to emphasize that we have identified key dimensions of the quality of health services through factor analysis, but there is no possibility to use this method to enter into a more detailed consideration.

Regardless of the limitations, based on empirical research we can conclude that the model of quality management of health services in public primary healthcare institutions is highly reliable, and that this methodology can help managers to minimize gaps in quality of health services, which would ultimately result continuous improvement of business processes in the health sector.

\section{REFERENCES}

1. Aghamolaei, T., Eftekhaari, T.E., Rafati, S., Kahnouji, K., Ahangari, S., Shahrzad, M.E., Kahnouji, E., Hoseini, S.H. (2014). Service quality assessment of a referral hospital in Southern Iran with SERVQUAL technique: patients' perspective, BMC Health Services Research, 1-5.

2. Amaravathi, M., Anand Shankar Raja, M, (2016). Assessing Servqual in Primary Healthcare Centres (PHC): With Special Reference to the City of Coimbatore, International Journal of Pharmaceutical Sciences Review and Research, 38(1), 5157.

3. Babakus, E. 1., Mangold, W.G. (1992). Adapting the SERVQUAL Scale to Hospital Services: An Empirical Investigation, https://pubmed.ncbi.nlm.nih.gov/1737708/

4. Brajić, A., Dedić, S., Brajić, S. (2021). Dimensions of healthcare services quality based on expectations of primary care users using factor analysis, 10th International scientific symposium region, entrepreneurship, development, Osijek, 623-636.

5. Čakalić, S. (2018). Zadovoljstvo bolesnika kvalitetom pruženih usluga zdravstvene skrbi u kliničkom zavodu za nuklearnu medicinu i njegu od zračenja, Diplomski rad.

6. Hair, J. F., Anderson, R., Tatham, R., Black W. (1998). Multivariate Data Analysis, 5th Ed., Englewood Cliff s, NJ: Prentice Hall.

7. Huseinspahić, N. (2012). Measurement of influence of patients' expectations to perceived service quality by using weighted SERVQUAL model, Zbornik radova, Ekonomski fakultet Univerziteta u Zenici, BH EKONOMSKI FORUM, godina 3, broj 4, Central end Eastern European Online Library, (CEEOL), ISSN 1986-681X, 35-53. 
8. Kljaić, M. (2017). Upravljanje kvalitetom u zdravstvenoj njezi, Diplomski rad

9. Mečev, D., Goleš, K. I. (2015). Primary healthcare service quality measurement: SERVQUAL scale, Ekonomski vjesnik, 28(1), 161-177.

10. Miranda, F.J., Mera, A.C., Hernandez, M.I.S., Murillo, L.R., Cervera, J.V., (2009). Adapting the SERVQUAL scale to primary healthcare services in Spain, 8th International Congress of the International Association on Public and Nonprofit Marketing At: Valencia (Spain)

11. Ozretić, D. Đ, Škare, V, Škare, T. (2010). Mjerenje kvalitete usluge primarne zdravstvene njege SERVQUAL instrumentom, Rev soc polit. 2010, 17(1), 27-44.

12. Papanikolaou, V., Zygiaris, S. (2014). Service quality perceptions in primary healthcare centres in Greece, Health Expect, 17(2), 197-207.

13. Šiško-Kulišić, M., Grubišić, D. (2010). Upravljanje kvalitetom, Ekonomski fakultet Sveučilišta u Splitu

14. Stojičić, A. M. (2017). Kvaliteta laboratorijskih usluga medicinskobiokemijskog laboratorija, Diplomski rad

15. Tabachnick, B. G., Fidell, L. S. (2007). Using multivariate statistics, 5th edition, Boston: Pearson Education

16. Teshnizi, S.H., Aghamolaei, T., Kahnouji, K., Teshnizi, S.M.H., Ghani, J. (2018). Assessing quality of health services with the SERVQUAL model in Iran. A systematic review and meta-analysis, International Journal for Quality in Healthcare, 30(2), 82-89. 


\title{
DIMENZIJE KVALITETE ZDRAVSTVENIH USLUGA BAZIRANE NA PERCEPCIJI KORISNIKA PRIMARNE ZDRAVSTVENE NJEGE UZ PRIMJENU FAKTORSKE ANALIZE
}

\author{
Aldin Brajić, Samira Dedić \& Saliha Brajić
}

\begin{abstract}
Sažetak
U suvremenom poslovnom okruženju zahtjev za kvalitetnijim zdravstvenim uslugama postaje imperativ. Otvorenost tržišta u području primarne zdravstvene njege dovela je javne zdravstvene ustanove do primjene koncepta upravljanja kvalitetom kao ključnog instrumenta u borbi protiv konkurencije. Ovaj se rad nadovezuje na prethodno objavljenu studiju o očekivanjima korisnika primarne zdravstvene njege, koja se sada usredotočuje na njihovu percepciju i prepoznavanje praznina kako bi se razvio konačni model upravljanja kvalitetom primarne zdravstvene njege. Istraživanje je provedeno korištenjem modificiranog anketnog upitnika SERVQUAL na kontroliranom slučajnom uzorku od 300 korisnika primarne zdravstvene njege u devet općina Tuzlanskog kantona Bosne i Hercegovine. Korištena je eksplorativna faktorska analiza glavnih komponenata na temelju ortogonalne rotacije VARIMAX. Opći cilj istraživanja je korištenje znanstvenih metoda za izgradnju konačnog modela upravljanja kvalitetom zdravstvenih usluga u javnim ustanovama primarne zdravstvene njege. Na temelju postavljenog cilja definirana je središnja hipoteza koja kaže da je primjenom faktorske analize moguće identificirati ključne dimenzije i atribute kvalitete zdravstvene usluge s aspekta percepcije korisnika primarne zdravstvene njege. Istraživanje potvrđuje postojanje odabranih četiri dimenzija kvalitete zdravstvenih usluga na ljestvici percepcije, pa su izneseni zaključci $i$ prijedlozi za menadžere primarne zdravstvene njege. Ograničenje istraživanja odnosi se na geografsko ograničenje odabranog uzorka, te se preporučuje proširenje istraživanja na cijelo područje Bosne i Hercegovine.
\end{abstract}

Ključne riječi: zdravstvena njega; faktorska analiza; korisnička percepcija; kvaliteta usluga; model. 